\title{
38
}

\section{Investor-state dispute settlement}

\author{
Kyla Tienhaara
}

\section{Introduction}

In 2011, in a small court in Ecuador's Amazon jungle, a judge ordered the American oil giant Chevron to pay US\$9 billion (AU $\$ 12$ billion) in damages for pollution in the region caused by drilling activities in the 1970s and 1980s. The company quickly denounced the landmark ruling as illegitimate. More than a year before the final ruling had been issued, Chevron had already taken steps to initiate an investor-state dispute against the Government of Ecuador under the terms of a United StatesEcuador bilateral investment treaty (BIT). The company seeks to avoid paying the $\$ 9$ billion by convincing an international tribunal that the courts of Ecuador are corrupt and that the government is ultimately responsible for any environmental damage and associated health issues experienced by local residents.

In the same year, only days after a tsunami struck Japan, leading to the Fukushima nuclear disaster, German Chancellor Angela Merkel announced the closure of Germany's oldest operating nuclear power plants. Shortly thereafter, the government moved to phase out all nuclear power by 2022 . While German society has embraced this policy move, unsurprisingly, nuclear power companies in the country did not. In 2012, after months of threatening to take the government to arbitration, the Swedish energy company Vattenfall finally launched its case under the provisions of the Energy Charter Treaty, an international 
trade and investment agreement in the energy sector. Press reports have suggested that Vattenfall will claim $€ 4.7$ billion (AU $\$ 7$ billion) in compensation for the closure of its two nuclear power plants. The company reached a settlement with the government in a previous dispute over the regulation of a coal-fired power station.

On the other side of the world, Australia was introducing legislation in 2011 that requires that all tobacco products be sold in plain brown packaging. Health warnings would still be included on cigarette packets, but logos would disappear. Several companies challenged the legislation as an expropriation of their intellectual property in Australia's High Court. They lost. However, one company was also able to pursue its case for compensation in international arbitration. Philip Morris International restructured its investment through its Asian subsidiary to access arbitration under a BIT between Hong Kong and Australia. The company was no stranger to arbitration, as it had already launched a dispute against Uruguay for similar tobacco packaging requirements.

Over the past decade, there has been an explosive increase in cases of investor-state dispute settlement (ISDS). Until the mid-1990s, only a handful of cases had emerged. Then, following a few high-profile cases, everything changed. Between 2003 and 2013, one arbitral body registered more than 30 new cases every year and more than 50 cases in each of the last three years of that 10-year period (UNCTAD 2014). As of the end of 2014, there were 608 known cases. By then, 101 governments had responded to one or more ISDS claims (UNCTAD 2015).

As the above examples demonstrate, what is notable is not just the number of disputes that have arisen, or the number of states that have been involved, but also the particular nature of disputes that have emerged. Rather than solely involving straightforward incidences of nationalisation or breach of contract, modern investor-state disputes often revolve around public policy measures and implicate sensitive issues such as health and environmental protection.

How did such matters become the purview of unelected ad hoc panels whose expertise lies in the realm of commercial law? The answer is not immediately evident. It could be argued that states themselves are the ones responsible. Governments have quietly been negotiating bilateral and regional investment agreements (collectively referred to as international investment agreements (IIAs)) that provide foreign investors with considerable legal protection and access to international 
arbitration. There are more than 3,200 such agreements in existence (UNCTAD 2015). Governments, particularly in developing countries, also sign contracts directly with foreign investors that contain similar privileges (or 'rights', depending on one's view).

However, although states may have opened the door to ISDS, they arguably did not anticipate that arbitral tribunals would reach so far into the public policy domain. IIAs were ostensibly created to promote foreign investment in developing countries and designed to protect investors from discrimination and particularly egregious conduct on the part of the host state. While the performance of investment agreements in helping states to attract investment is debatable, the success investors have had in convincing arbitrators to stretch the traditional meaning of clauses on 'expropriation' and 'fair and equitable treatment' is undeniable.

This chapter examines the system of ISDS and its importance in global affairs. First, the basis for the system-a complex web or 'spaghetti bowl' (as it is sometimes called) of bilateral and regional investment agreements - is outlined. Second, the authority of arbitral tribunals, and how this authority has expanded over time, is discussed. The chapter then turns to the cost of investment arbitration for states, both in hard monetary terms and in terms of the unquantifiable costs of 'regulatory chill'. Finally, the current backlash from some states against investment arbitration is examined. The chapter concludes that the future for ISDS is not bright, as, increasingly, even the traditional champions of the system (developed countries) are beginning to question its merit.

\section{The spaghetti bowl}

As there is not an unlimited supply of investment that is equally distributed around the world, it is often argued that states must compete for foreign direct investment (FDI). Governments compete for investment by providing incentives (such as tax holidays, loan guarantees and cash grants) and also by differentiating their legal jurisdictions from those of their competitors. In this latter sense, legal reform has become an important tool for developing countries in their bid to attract FDI.

Domestic measures, although important for signalling, are limited by the 'credible commitment' problem - that is, governments cannot demonstrate to investors in a meaningful way that a country's 'investment environment' will not simply be changed once investors have established 
themselves in the country and have substantial sunk costs. Furthermore, due to the perceived or real corruption of the courts in many countries, investors do not view local remedies as a neutral or fair option for the resolution of disputes. This is the reasoning behind the development of the system of ISDS.

The first proposal for ISDS emerged in the 1959 Abs-Shawcross Draft Convention on Investment Abroad (Newcombe and Paradell 2009). Businesspeople rather than governments drafted this document, but it provided a model that proved to be extremely attractive to developed countries and was taken up by the Organisation for Economic Co-operation and Development (OECD) in its Draft Convention on the Protection of Foreign Property of 1962. While the OECD draft convention was never adopted due to opposition from some member states, it was revised in 1967 and approved by the council of the OECD as a model for BITs.

The first BIT containing an ISDS clause was signed between Italy and Chad in 1969. While the pace of BIT signing was initially slow, this changed in the 1990s. In the period following the 1982 debt crisis, most developing countries shifted from an antagonistic or ambivalent approach to FDI to the active courting of foreign investors (Van Harten 2007). In this environment, BITs - designed to provide investment protection-were presented to developing countries as vehicles for investment promotion. This 'mechanism of reward' (in the terminology of Drahos, Chapter 15, this volume) was central to the spread of BITs. Unfortunately, research suggests that BITs may not actually have any impact on flows of FDI (Yackee 2008; Aisbett 2009).

In addition to hoping to attract FDI, many governments in developing countries were pressured by developed countries and international finance institutions to sign BITs. José Alvarez, a former member of the US BIT negotiating team, has acknowledged that a BIT is 'hardly a voluntary, uncoerced transaction' (quoted in Garcia 2004: 316). The most economically and politically powerful developing countries have managed to avoid BITs; Brazil has signed several, but never ratified one, and China's BITs have historically been quite strictly circumscribed.

OECD countries participate in BITs almost exclusively with developing countries; while there is an increasing number of global South-South BITs, there is a dearth of agreements between industrialised nations. On the other hand, there are a number of bilateral and regional 
free-trade agreements between developed countries that have chapters on investment, the most famous being the North American Free Trade Agreement (NAFTA). NAFTA's Chapter 11 on investment marks a significant milestone in investment law, despite the fact that the language of many of the provisions in the agreement is essentially drawn, with relatively minor modifications, from BITs that the United States had concluded prior to 1993. It is noteworthy because investors have extensively employed ISDS under Chapter 11, marking a new era of investment arbitration, and arguably triggering the current surge in disputes brought under other agreements. Despite the fact that the investment chapter was largely aimed at constraining Mexico, investors have made claims against all three signatory countries and Canada has actually faced the largest number of disputes.

Attempts have been made to enshrine ISDS in a global treaty on investment. In 1995, negotiations on a multilateral agreement on investment (MAI) were commenced under the auspices of the OECD. While the OECD is not a global forum, the MAI, once completed, would have been opened up for signature by any country. However, disagreements among members of this 'like-minded' club were more intractable than expected and ardent opposition to the agreement from civil society also complicated the negotiations. In 1998, the MAI talks fell apart. There remains debate over whether non-governmental organisations (NGOs) and the 'anti-globalisation' movement 'killed' the MAI through their campaigns to pressure governments or if, instead, OECD countries simply failed to find common ground on certain key issues (Graham 2000; Muchlinski 2001).

In 2003, debates about an MAI once again came to the fore, at the World Trade Organization (WTO) Ministerial Conference in Cancun, Mexico. These talks were also a dramatic failure. In a classic example of forum shifting (see Drahos, Chapter 15, this volume), the United States and other countries have since refocused their efforts on negotiating regional agreements, such the United States-Central America Free Trade Agreement (CAFTA) and the Trans-Pacific Partnership (TPP) Agreement, as well as more BITs. These 'minilateral' agreements are easier to negotiate and generally garner less attention from NGOs (although this has not been the case with the TPP). The result is effectively near global coverage of investment protection (particularly because corporations can shift nationality; see below), but in a complex and confusing patchwork of rules. 


\section{The expansion of arbitral authority}

IIAs appear deceptively mundane at first glance. Essentially, they are reciprocal agreements between states to provide investors from one state with legal protection when they are operating within the territory of the other state(s). The precise content of IIAs varies to a certain degree. Generally speaking, IIAs contain provisions on national treatment, mostfavoured nation treatment, fair and equitable treatment/the minimum standard of treatment and expropriation (Sornarajah 2004). However, these standards are very vague and they are consequently open to a considerable amount of interpretation. Experience has demonstrated that minor variations in wording can have substantial consequences for governments.

As there is no global treaty on investment, there is also no international investment court (although the European Union has recently proposed the creation of one). Instead, one-off arbitral tribunals review the cases launched by investors and interpret the provisions in IIAs. Procedurally, these tribunals follow established arbitration rules, typically those developed by the United Nations Commission on International Trade Law (UNCITRAL) or the International Centre for Settlement of Investment Disputes (ICSID). Regardless of what rules are chosen by the investor, the tribunal will have three members: one chosen by the investor, one chosen by the state and a third who is mutually agreed on and will act as president. Barristers and retired judges are not the only ones who are frequently appointed as arbitrators, but also professors, who, in many cases, also have careers as leading private lawyers.

From the historical context in which IIAs were first developed, one can extrapolate what states intended to give arbitrators authority over: the resolution of certain types of disputes that might arise between a government of one party to an IIA and an investor from one of the other parties to the IIA. Their intention was not to extend protection to all investors, but only to those who were domiciled in one of the other parties to the IIA. Furthermore, their intention was not to delegate to arbitrators the authority to resolve every possible type of dispute that could arise between an investor and a government. The expansion of arbitrator authority in recent years stems from arbitrator movement away from the intentions of states both in terms of who should be protected under IIAs and what constitutes a breach of treaty. 
On the issue of who should be protected, there are ongoing debates about the definition of the fundamental terms 'investor' and 'investment', but another fundamental problem is 'treaty shopping'-when a multinational corporation establishes a holding company in one IIA party to access arbitration when a dispute arises over its investment in the territory of another IIA party (Van Harten and Loughlin 2006). One oft-cited example of a treaty shopping investor is the American firm Bechtel. When a dispute arose over its investment in Bolivia, Bechtel established a subsidiary in the Netherlands to access arbitration through that country's BIT with Bolivia (the United States-Bolivia BIT was not in force at the time). As noted in the introduction, Philip Morris International also engaged in treaty shopping to bring a suit against Australia, although, in this instance, the strategy backfired as the panel ruled that it did not have jurisdiction over the case.

Tribunals that have determined that they do have the jurisdiction to hear the claims of treaty shopping investors have expanded arbitration beyond what was intended by states when they established reciprocal relationships with other states through IIAs. Domestic investors have even used this method to gain access to treaty protection against their own government. Sornarajah (2010:280) argues that it 'could never have been the intention of any state' to protect domestic investors through IIAs, as the unambiguous aim of these agreements was to protect and promote foreign investment.

In terms of what constitutes a breach of an IIA, prior to the mid-1990s, when ISDSs began to flourish, only very dramatic actions by a state that were clearly directed at an investor (for example, an expropriation of property or a blatant act of discrimination) were seriously contemplated as breaches of international law. However, in more recent cases, several standard investment provisions have been interpreted in such a broad manner that it would appear that (at least some) arbitrators believe that it is within their purview to review any state regulatory action, or indeed inaction, that has a negative (not necessarily devastating) impact on a foreign investor or investment.

The clearest example of this is the arbitration-induced evolution of the 'fair and equitable treatment' standard. Several tribunals have moved away from the traditional customary international law understanding of this term (requiring states to provide a 'minimum' standard of treatment including access to justice) and have advocated a 'plain meaning' interpretation that requires a state to: comply with the tenets of 
'good governance', maintain a 'stable and favourable investment climate' and meet the 'legitimate expectations' of foreign investors. Such a capacious standard effectively allows tribunals to review any regulatory measure, even if it was enacted in the public interest (for example, to protect the environment; see further Tienhaara 2009).

The evolution of the fair and equitable treatment standard illustrates very well the idea that the regulatory state and regulatory capitalism are not solely about deregulation, but instead involve the creation of new rights and an element of re-regulation (see Scott, Chapter 16; and Levi-Faur, Chapter 17, this volume). To comply with the fair and equitable treatment standard, as defined by some tribunals, states are not only required to refrain from certain actions that would interfere in the operation of an investment, but also obliged to proactively take certain steps (for example, to ensure transparency when policies that affect investors are being developed). In other words, the state is being asked to do both more and less at the same time.

By expansively interpreting both who is protected by IIAs and what IIA protection entails, arbitrators have pushed the bounds of the authoritative space that had been carved out for them by states. In some respects, ISDS tribunals resemble the transnational non-state regulatory regimes discussed by Tusikov (Chapter 20, this volume). Although the 'rules' of investment protection are ostensibly created by states (undoubtedly with input from corporate lobbyists), they are so vague that they are only given meaning when they are applied to specific facts and are filtered through the ideological lens of an arbitrator. As such, arbitrators are effectively creating rules and acting as regulators. Given the absence of appropriate accountability mechanisms to accompany such a role, there is an understandable feeling (expressed even by those within the system) that the legitimacy of ISDS is increasingly in doubt (Van Harten 2007; Sornarajah 2010).

\section{How BITs bite}

It has been said that 'the awards of arbitrators are more widely enforceable than any other adjudicative decision in public law' (Van Harten 2007: 5). IIAs often explicitly obligate states to recognise awards, thus allowing investors to seek enforcement in the local courts of the host state. Furthermore, where an IIA provides for enforcement 
under the Convention on the Settlement of Investment Disputes between States and Nationals of Other States (ICSID Convention), an investor can seek enforcement in the domestic courts of any state party to the convention. Awards may also be enforceable under other arbitration treaties such as the Convention on the Recognition and Enforcement of Foreign Arbitral Awards (New York Convention).

Tribunals are given a significant degree of discretion to determine damages, which may include a company's 'lost future profits'. Many ISDS claims now exceed US\$1 billion (AU $\$ 1.3$ billion) and, although the compensation actually awarded is generally much lower than what is sought, the impact on the public purse can be substantial. The Czech Republic was obliged to pay more than US $\$ 350$ million (AU $\$ 460$ million) in compensation to a Dutch investor, which, according to one report, meant a near doubling of the country's public sector deficit (IISD 2007). In 2014 the US $\$ 1.77$ billion (AU $\$ 2.33$ billion) award against Ecuador (brought by Occidental Petroleum)—previously the largest known ISDS award in history - was vastly outstripped by a mindboggling US $\$ 50$ billion (AU $\$ 66$ billion) award against Russia in its high-profile dispute with the oil company Yukos.

Even if a state wins a case it may be costly. International arbitration was originally seen as a cheaper and quicker alternative to domestic courts, but it is actually very expensive and cases can drag on for years. An OECD survey shows that legal and arbitration costs for the parties in ISDS cases have averaged over US\$8 million (AU $\$ 10.5$ million), with costs exceeding US\$30 million (AU $\$ 39$ million) in some cases (Gaukrodger and Gordon 2012). Australia is reported to have spent AU $\$ 50$ million in its dispute with Philip Morris-a case that never even proceeded to the merits phase.

The considerable procedural costs associated with arbitration as well as the risk of having to pay large awards have led some scholars to suggest that the mere threat of an investor-state dispute could chill the development of regulation in the public interest. Peterson (2004: 139) notes that practicing lawyers do admit that they hear rumours of investors applying informal pressure upon host states while brandishing an investment treaty as a potential legal stick'. In a globalised world, ISDS cases may also be initiated in one jurisdiction by investors hoping to deter the development of policies in other jurisdictions. This may, in part, explain Philip Morris's disputes with Uruguay and Australia over 
plain packaging of cigarettes - that is, the company may be hoping that the threat of arbitration will deter the development of similar labelling policies in other countries.

Occurrences of regulatory chill are incredibly difficult to prove (effectively, one has to find evidence of something that has not happened). Nevertheless, several scholars have put forward case studies that suggest that investor threats of arbitration had an impact on the development of specific policies (Schneiderman 2008; Tienhaara 2009, 2011).

\section{Once BITten, twice shy}

There is evidence that government officials in developing countries historically had a poor understanding of the risks posed by signing IIAs. For example, the Attorney-General of Pakistan, Makhdoom Ali Khan, has claimed that BITs 'are signed without any knowledge of their implications' and it is not until 'you are hit by the first investor-state arbitration [that] you realize what these words mean' (quoted in Peterson 2006). It is also made very clear in a government document from South Africa that BITs have had unanticipated policy consequences in that country: 'Prior to 1994, the RSA [Republic of South Africa] had no history of negotiating BITs and the risks posed by such treaties were not fully appreciated at that time' (DTI 2009: 5).

In fact, even the few developed countries that have faced investor-state disputes appear to have been taken aback by the scope of investment treaties, as interpreted by tribunals. For example, Stiglitz (2008: 460-1) suggests that US President Bill Clinton was unaware of the potential of NAFTA's Chapter 11 to be used to challenge government regulation, and goes on to point out that if:

the United States, a country with a great deal of experience adopting such agreements, was not fully aware of NAFTA's import, developing countries are even less likely to understand the complexities of such agreements.

The absence of evidence of any clear benefits of IIAs in terms of increased FDI flows, coupled with increasing concerns about the costs of the system, has led many countries to reconsider BITs and the inclusion of ISDS clauses in trade agreements. Reactions have ranged 
from the careful qualifying of certain treaty standards in new agreements to the more radical rejection of and withdrawal from BITs and arbitral institutions.

Despite the fact that the United States has never lost a case, there is considerable opposition to ISDS from both left-wing and right-wing political parties and groups in America (even the Cato Institute has come out against ISDS; see Ikenson 2014). Nevertheless, the government has opted to continue to strongly support the system while introducing a number of reforms. The content of the US Model BIT (used as a template in all IIA negotiations) was revised in 2004 and 2012 to clarify the meaning of several provisions and also to increase the transparency of the ISDS process.

Other countries, such as Canada and Colombia, have also revised their model BITs in ways that restrict the discretion of arbitrators. Interestingly, Norway-a country that ceased signing BITs in the mid1990s due, in part, to concerns about their policy implications-formed a working group to develop a new model in 2006. However, the public debate about the new model was so polarised-one side arguing that the model did not provide investors with enough protection and the other suggesting that it would restrict the government's ability to regulate in the public interest-that, in the end, it was shelved (Vis-Dunbar 2009).

Norway's initiatives in this area, though ultimately unsuccessful, have been much more innovative than those taken in other Western European countries, where BITs have, by and large, remained short, simple and vague documents. However, as a result of the 2009 Treaty of Lisbon, the negotiation of IIAs now falls under the exclusive competence of the European Commission (EC). In April 2011, the European Parliament released a resolution on the future of European international investment policy, which expressed the parliament's 'deep concern regarding the level of discretion of international arbitrators to make a broad interpretation of investor protection clauses' and called on the European Commission to 'produce clear definitions of investor protection standards in order to avoid such problems in the new investment agreements' (European Parliament 2011: para. 24).

The debate about ISDS in Europe has since intensified. Negotiations for the Comprehensive Economic and Trade Agreement (CETA) with Canada concluded in October 2013, but, in January 2015, France and Germany requested that the European Commission review the treaty 
and remove or modify the ISDS provisions. In part, this is an attempt to also steer the ongoing negotiations in the Transatlantic Trade and Investment Partnership (TTIP) with the United States. The results of a public consultation on ISDS in the TTIP resulted in over 150,000 submissions, the majority of which expressed opposition to its inclusion in the treaty.

Australia has also had a complicated relationship with ISDS. The Australia-United States Free Trade Agreement, signed by the conservative Howard Government in 2004, excluded ISDS. Australia subsequently negotiated several agreements containing ISDS, but, in April 2011, the Gillard Labor Government discontinued this practice. The Gillard Government's policy was that it would not support:

provisions that would confer greater legal rights on foreign businesses than those available to domestic businesses ... [or] provisions that would constrain the ability of Australian governments to make laws on social, environmental and economic matters in circumstances where those laws do not discriminate between domestic and foreign businesses. (DFAT 2011)

The Abbott Government then abandoned this policy, opting to approach ISDS on a case-by-case basis, accepting it in treaties with South Korea and China but excluding it in one with Japan (which is rendered irrelevant in the event that the TPP comes into force). The change in policy provoked a Greens senator to propose a piece of legislation that would prohibit the government from agreeing to ISDS in any treaty in the future (Whish-Wilson 2014).

Developing countries have, by and large, been most affected by ISDS and have also reacted the most strongly against it. BITs have been unilaterally terminated by Venezuela, Bolivia, Ecuador and South Africa (UNCTAD 2013). It has also been reported that Indonesia is considering terminating all of its BITs. In 2015, India released a model BIT that is a radical departure from traditional agreements, and is particularly notable for its exclusion of any reference to 'fair and equitable treatment'.

Bolivia, Ecuador and Venezuela have all denounced the ICSID Convention. In explaining the move, Bolivia's Trade Ambassador Pablo Solon suggested that arbitration is expensive and biased against developing countries (Fairies 2007). The first seeds of Bolivian discontent with ICSID were likely sown during the controversial Aguas Del Tunari case (a dispute over a water privatisation contract, often referred to as 
Bolivia's 'water war'). At the time Ecuador made its denunciation, the country was facing more than US $\$ 12$ billion (AU $\$ 16$ billion) worth of ICSID-based ISDS claims. The withdrawal of these countries from ICSID does not affect ongoing cases and future cases may still arise under other arbitration rules. Nevertheless, the move away from ICSID sends a strong message to the international community that these countries are dissatisfied with ISDS.

\section{Conclusion}

The future of ISDS is uncertain. Although some governments continue to sign IIAs, they are doing so at a much slower pace than in the 1990s. While this is in part a result of the inevitable exhaustion of potential treaty partners, it also reflects increasing doubts about the value of the system. As the number of new treaties declines, the content of those that do emerge is also evolving in a way that reduces arbitrator discretion and, thus, authority.

At the same time, record numbers of investors are making use of ISDS through existing IIAs. As cases pile up and more information about these cases becomes available (in part due to increases in the transparency of the ISDS process), opposition from civil society intensifies. Complaints about ISDS are not limited to one end of the political spectrum; farmers who want to be able to 'lock the gate' to coalseam gas exploration companies share the same concerns about ISDS as do environmental NGOs.

Strong reactions against ISDS are also no longer confined to 'radical left-leaning' governments in Latin America; steps to withdraw from ISDS or limit its application have been taken by governments with very different perspectives on broader issues of globalisation and trade liberalisation. What appears to be the common thread linking governments that have taken action on this issue is a negative experience with arbitration. This would tend to suggest that, in the coming years, as more states are exposed to ISDS claims, discontent with the system will grow.

Alternatively, it is possible that arbitrators will recognise that the writing is on the wall (as they did when ISDS was identified as being overly 'secretive') and will begin to self-regulate to avoid further circumscription of their powers or the complete abandonment of the 
system. However, such restraint may equally doom ISDS to obscurity because, if the main clients of the system (only investors can bring suits) do not view it as beneficial (for example, if they do not have a high likelihood of winning), they will look elsewhere for the means to achieve their objectives.

\section{Further reading}

Bonnitcha, J 2014. Substantive Protection under Investment Treaties: A Legal and Economic Analysis. Cambridge: Cambridge University Press. doi.org/10.1017/CBO9781107326361.

Investment Arbitration Reporter n.d. [Subscription]. Santa Monica, CA. Available at: iareporter.com.

Investment Treaty News 2016. Website. Winnipeg: International Institute for Sustainable Development. Available at: iisd.org/itn/.

Sornarajah, M 2015. Resistance and Change in the International Law on Foreign Investment. Cambridge: Cambridge University Press. doi. org/10.1017/CBO9781316156339.

United Nations Conference on Trade and Development (UNCTAD) n.d. International Investment Agreements: Publications. Geneva: UNCTAD. Available at: unctad.org/en/Pages/DIAE/International \%20Investment\%20Agreements\%20(IIA)/IIA-Publications.aspx.

\section{References}

Aisbett, E 2009. 'Bilateral investment treaties and foreign direct investment: Correlation versus causation', in K Sauvant and L Sachs (eds), The Effect of Treaties on Foreign Direct Investment: Bilateral Investment Treaties, Double Taxation Treaties and Investment Flows. Oxford: Oxford University Press, pp. 395-436. doi.org/10.1093/ acprof:oso/9780195388534.003.0015.

Department of Foreign Affairs and Trade (DFAT) 2011. 'Gillard Government trade policy statement: Trading our way to more jobs and prosperity', Press release, 12 April, Government of Australia, Canberra. 
Department of Trade and Industry (DTI) 2009. 'Bilateral investment treaty policy framework review: Executive summary of government position paper', Government Gazette, 7 July. Pretoria: Republic of South Africa.

European Parliament 2011. Resolution of 6 April 2011 on the future European international investment policy, (2010/2203(INI)), 6 April, European Parliament, Strasbourg. Available at: europarl.europa. eu/sides/getDoc.do?pubRef=-//EP//TEXT+TA+P7-TA-20110141+0+DOC+XML+V0//EN .

Fairies, B 2007. 'Bolivia will withdraw from dispute panel, Solon says', Bloomberg, 31 May.

Garcia, C 2004. 'All the other dirty little secrets: Investment treaties, Latin America, and the necessary evil of investor-state arbitration', Florida Journal of International Law 16: 301-69.

Gaukrodger, D and Gordon, K 2012. Investor-state dispute settlement: A scoping paper for the investment policy community, OECD Working Papers on International Investment No. 2012/3, OECD, Paris. Available at: oecd.org/daf/inv/investment-policy/WP-2012_3.pdf.

Graham, EM 2000. Fighting the Wrong Enemy: Antiglobal Activists and Multinational Enterprises. Washington, DC: Institute for International Economics.

Ikenson, D 2014. 'A compromise to advance the trade agenda: Purge negotiations of investor-state dispute settlement', Free Trade Bulletin (57), 4 March. Available at: cato.org/publications/free-tradebulletin/compromise-advance-trade-agenda-purge-negotiationsinvestor-state.

International Institute for Sustainable Development (IISD) 2007. 'A parliamentarian's guide to international investment agreements and their implications for domestic policy-making', ILA Insighter (Spring). Available at: iisd.org/investment/resources/insighter.asp.

Muchlinski, P 2001. 'The rise and fall of the multilateral agreement on investment: Lessons for the regulation of international business', in IF Fletcher, M Cremona and LA Mistelis (eds), Foundations and Perspectives of International Trade Law. London: Sweet \& Maxwell, pp. 114-34. 
Newcombe, A and Paradell, L 2009. Law and Practice of Investment Treaties: Standards of Treatment. The Hague: Kluwer Law International.

Peterson, L 2004. 'All roads lead out of Rome: Divergent paths of dispute settlement in bilateral investment treaties', in L Zarsky (ed.), International Investment for Sustainable Development: Balancing Rights and Rewards. London: Earthscan, pp. 123-49.

Peterson, L 2006. 'Pakistan attorney general advises states to scrutinize investment treaties carefully', Investment Treaty Nerws, 1 December. Available at: iisd.org/investment/itn.

Roberts, A 2010. 'Power and persuasion in investment treaty interpretation: The dual role of states', American Journal of International Law 104(2): 179-225. doi.org/10.5305/ amerjintelaw.104.2.0179.

Schneiderman, D 2008. Constitutionalizing Economic Globalization: Investment Rules and Democracy's Promise. Cambridge: Cambridge University Press.

Sornarajah, M 2004. The International Law on Foreign Investment. 2nd edn. Cambridge: Cambridge University Press.

Sornarajah, M 2010. 'The retreat of neo-liberalism in investment treaty arbitration', in CA Rogers and RP Alford (eds), The Future of Investment Arbitration. Oxford: Oxford University Press, pp. 273-96. doi.org/10.1017/CBO9780511617027.

Stiglitz, J 2008. 'Regulating multinational corporations: Towards principles of cross-border legal frameworks in a globalized world-Balancing rights with responsibilities', American University International Law Review 23(3): 451-558.

Tienhaara, K 2009. The Expropriation of Environmental Governance: Protecting Foreign Investors at the Expense of Public Policy. Cambridge: Cambridge University Press.

Tienhaara, K 2011. 'Regulatory chill and the threat of arbitration: A view from political science', in C Brown and K Miles (eds), Evolution in Investment Treaty Law and Arbitration. Cambridge: Cambridge University Press, pp. 606-27. doi.org/10.1017/ CBO9781139043809.034. 
United Nations Conference on Trade and Development (UNCTAD) 2013. International investment policymaking in transition: Challenges and opportunities of treaty renewal, IIA Issues Note No. 4, June, UNCTAD, Geneva.Available at: unctad.org/en/PublicationsLibrary/ webdiaepcb2013d9_en.pdf.

United Nations Conference on Trade and Development (UNCTAD) 2014. Recent developments in investor-state dispute settlement, IIA Issues Note No. 1, April, UNCTAD, Geneva. Available at: unctad.org/en/PublicationsLibrary/webdiaepcb2014d3_en.pdf.

United Nations Conference on Trade and Development (UNCTAD) 2015. Recent trends in ILAs and ISDS, IIA Issues Note No. 1, February, UNCTAD, Geneva. Available at: unctad.org/en/ PublicationsLibrary/webdiaepcb2015d1_en.pdf.

Van Harten, G 2007. Investment Treaty Arbitration and Public Law. Oxford: Oxford University Press.

Van Harten, G and Loughlin, M 2006. 'Investment treaty arbitration as a species of global administrative law', European Journal of International Law 17(1): 121-50. doi.org/10.1093/ejil/chi159.

Vis-Dunbar, D 2009. 'Norway shelves its proposed model bilateral investment treaty', Investment Treaty News, 8 June. Available at: iisd. org/investment/itn.

Whish-Wilson, P 2014. 'Investor-state dispute settlement', Press release, 14 March, Launceston, Tas.

Yackee, JW 2008. 'Bilateral investment treaties, credible commitment, and the rule of (international) law: Do BITs promote foreign direct investment?', Law E Society Review 42(4): 805-32. doi.org/10.1111/ j.1540-5893.2008.00359.x. 
This text is taken from Regulatory Theory: Foundations and applications, edited by Peter Drahos, published 2017 by ANU Press, The Australian National University, Canberra, Australia. 